\title{
Evolution of Coal Ash Solidification Properties with Disposal Site Depth and Age, "Gacko" Thermal Power Plant Case
}

\author{
DINKO N. KNEŽEVIĆ, University of Belgrade, \\ Faculty of Mining and Geology, Belgrade \\ DRAGANA N. NIŠIĆ, University of Belgrade, \\ Original scientific paper \\ Faculty of Mining and Geology, Belgrade \\ UDC: 628.472.3.034:621.311.22(497.6) \\ 613.164 \\ DOI: 10.5937/tehnika1702195K \\ SRETEN M. BEATOVIĆ, Thermal power plant "Gacko", Gacko \\ Republic of Srpska, Bosnia and Herzegovina, \\ ALEKSANDRA Đ. TOMAŠEVIĆ, University of Belgrade, \\ Faculty of Mining and Geology, Belgrade
}

\begin{abstract}
Ash with high calcium content is produced by coal combusting in "Gacko" thermal power plant (Bosnia and Herzegovina). Result of controlled mixture of water and ash is spontaneous ash solidification on disposal site. Speed and solidification efficiency depends on content of calcium-oxide in ash and water: ash mass ratio, which was determined by previous research. Mass ratio that was chosen as the most suitable ratio for industrial usage (roughly) was 1:1. Samples of ash of different age were taken after 6.5 years of exploitation and their chemical, physical, mineralogical and geotechnical characteristics were analyzed. Disposed ash was stratified and very heterogeneous. It was shown that great impact on solidification process in practice have climate conditions, proper handling slurry processing, work continuity and disposal site preparation. Great impact of water is noticed which is, because of its water permeability filtrated into lower layers and significantly alters it characteristic.
\end{abstract}

Key words: TPP "Gacko" ash disposal site, high calcium ash, spontaneous solidification, characteristics of disposed ash

\section{INTRODUCTION}

More than 700 million tons of ash is produced from coal worldwide [1]. It gives ratio of $100 \mathrm{~kg}$ of ash per 1 inhabitant per year and while Earth is concerned it goes to $47 \mathrm{~kg} / \mathrm{km}^{2}$. China, USA and India are countries where the most of ash is produced. Comparing to countries surface the most unfavorable situation is in Greece, $91.3 \mathrm{t} / \mathrm{km}^{2}$. Bosnia and Herzegovina $(\mathrm{BiH})$ is close to the world's top place, $35.3 \mathrm{t} / \mathrm{km}^{2}$. If the load is compared to the inhabitants, then Greece is on the most unfavorable place again. Every inhabitant of Greece 'get' more than 1 ton of ash per year. The situation is slightly more favorable in $\mathrm{BiH}, 460 \mathrm{~kg}$ per inhabitant.

Lignite, with caloric value of $8000-8500 \mathrm{~kJ} / \mathrm{kg}$, is combusted in $300 \mathrm{MW}$ thermal power plant (TPP) "Gacko" (BiH). Annual production of ash is about

Author's address: Dinko Knežević, University of Belgrade, Faculty of Mining and Geology, Belgrade, Đušina 7, e-mail: dinko.knezevic@ @rgf.bg.ac.rs

Paper received: 16.03.2017.

Paper accepted: 27.03.2017.
400.000 tons. According the American ASTM C 618 standard ash from TPP "Gacko" is "class C" [2], by Russian it is "active" [3, 4] and by Serbian classification it is "calcium" [5]. The basic characteristic of these kind of ashes is linked to the possibility of spontaneous solidification on disposal site, if the slurry preparation conditions are adjusted to the content of active substance which is required to initiate solidification.

Solidification refers to techniques that encapsulate the waste, forming a solid material, and does not necessarily involve a chemical interaction between the contaminants and the solidifying additives. The product of solidification, often known as the waste form, may be a monolithic block, a clay-like material, a granular particulate, or some other physical form commonly considered "solid." $[6,7]$

There are several dozen ways of creating solidification. Solidified technologies are often classified based on the principal additives used to obtain a solid matrix. Various systems based on organic (bitumen, urea formaldehyde, polybutadiene, polyester, epoxy, 
polyethylene) and inorganic (cements, pozzolan-lime, pozzolan-cement, clay-cement, gypsum) additives. Another classification divided methods into six groups by the way of stabilization: self-solidification, by lime or cement adding, by silicate adding (silica gel or cement), thermo plastic impregnation (asphalt, bitumen, paraffin, polyethylene etc), impregnation of organic polymers (urea-formaldehyde for polymerization) and inorganic precipitation (ferric ions) [8].

Lime or cement adding and self-solidification are most commonly used to solidification nuclear or hazardous waste [8]. Mixing of fly ash with high concentration of calcium with nuclear waste and cement is often used to transfer nuclear waste into stabile state, i.e. to prevent any leachability from nuclear waste disposal sites. This technology is called chemical fixation and solidification (CFS) [9-15,].

In Malaysia, agricultural waste and waste from agro-processing industries were mixed with other toxic waste and it was combusted. Ash as a solid residue was solidified and stabilized by adding Portland cement [16]. A research has shown that cement can't successfully stabilize hard metals, so the process was improved by adding active coal and rice husk.

By using only Portland cement, compressive strength of solidified cement was going from 1.9 to $14.6 \mathrm{MPa}$. Additives were slightly decreased compressive strength so the result was $1.4-3.6 \mathrm{MPa}$ when active coal was added, i.e. 2.3 - 12.2 MPa when rice husk were added.

Air Pollution Control residues from Municipal Solid Waste Incineration (MSWI) solidification in low density polyethylene, polystyrene, polyvinyl chloride or on polymer blends were realized by co-rotating twin-screw extrusion $[17,18]$.

Environmental protection from MSWI leaching of toxic pollutants were done by solidification with lime and cement adding [18], only by cement [19], by milling and cement [20] and mixing with alkaline activated coal fly ash [21].

Solidification of ash which was made by combusting medical waste is done by cement adding. Stabile mass is formed of which does not come to leaching of hard metals and disposed material is geotechnical stabile [22, 23].

Russian authors [3, 4] who were researching the process of coal ash solidification concluded that because of the complexity of the composition of the system it is very hard to research the process, so they gave the precedence to the less complicated research of individual constituent phases.

Up to 40 minerals is noted in the ash composition. Those with various speed, bring in the reaction with water thus making hydration and hydrolyses products of various composition.

Solidification of ash from coal in an autoclave was researched in Japan [24]. Fly ash was first compacted under the pressure of 20 to $50 \mathrm{MPa}$ and then hydrothermally treated in an autoclave on the $150-250^{\circ} \mathrm{C}$ temperature during 15-60 hours. Mineral tobermorite or calcium silicate hydrate like tobermorite is formed by solidification. The hardest product was got when ratio $\mathrm{Cao} / \mathrm{SiO}_{2}$ was close to 0.83 . Compressive strength achieved under hydrothermal conditions was above $10 \mathrm{MPa}$.

Research of conditions of solidification of ash with low calcium content out of TPP "Kostolac-B" in Serbia gave positive results by using lime and bentonite, when participation of additives was 5-10\% [25]. Polish scientists patented method of ash solidification by adding additives: $\mathrm{CaO}, \mathrm{CaCl}_{2}, \mathrm{H}_{2} \mathrm{O}, \mathrm{KNO}_{3}, \mathrm{NaHSO}_{4}$ or $\mathrm{KHSO}_{4}$. Participation of additives is around $7.5 \%$ in comparison to ash mass. Eventually it leads to solidification (utmost for 10 days) where formed mass has water permeability, not higher of $1 \times 10^{-6} \mathrm{~m} / \mathrm{s}$ and compressive strength above $0.3 \mathrm{MPa}$ [26]. The disposing system has seen pilot scale usage on Polish TPP "Lagisa” [27].

Ash's self solidification has been noted in "Viskoza" heat power plant (Serbia) and on the hydraulic ash disposal site TPP Kosovo-A (Serbia, Kosovo and Metohia), on Estonian power plant "Estonskaja GRES" and on an ash disposal site TPP "Kakanj" (BiH). [28].

Spontaneous solidification in controlled conditions of preparation and ash disposal is noted on TPP "Kosovo-B" (Serbia, Kosovo and Metohia) ash disposal site. In the composition of the ash the most common material is oxides of calcium $(\mathrm{CaO})$ and silicon $\left(\mathrm{SiO}_{2}\right)$ - above $65 \%$. Ratio $\mathrm{CaO} / \mathrm{SiO}_{2}$ is $1.16-1.33$. Intensive hydratation is a consequence of its contact with water, it changes to $\mathrm{Ca}(\mathrm{OH})_{2}$ and afterwards it changes to tobermorite and ettringite. Dry ash had $31 \%$ of $\mathrm{CaO}$, after five day decrease to $4.3 \%$ and after 22 days it does not exist. This shows that after a period of 22 days solidification process in most of it ends. Compressive strength of disposed ash was above $17 \mathrm{MPa}$ [29].

\section{PRIOR RESEARCH OF TPP “GACKO” ASH SELF-SOLIDIFICATION}

Ash research with high content of calcium oxide, when it has contact with water in transport and disposal phase is done in the laboratory and in the pilot plant scale on the location of TPP "Gacko" [30].

Depending of mass ratio, it comes to turbulent exothermic reaction. When the mass concentration of ash is below $40 \%$ (zone A on Figure 1) there is not 
complete binding of technological water and swiftness of the reaction is slow.

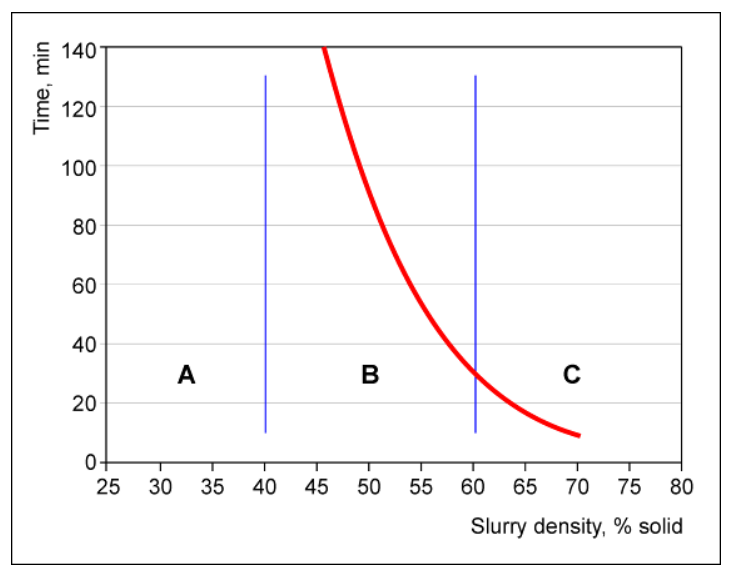

Figure 1 - Time of binding technological water in function of slurry density

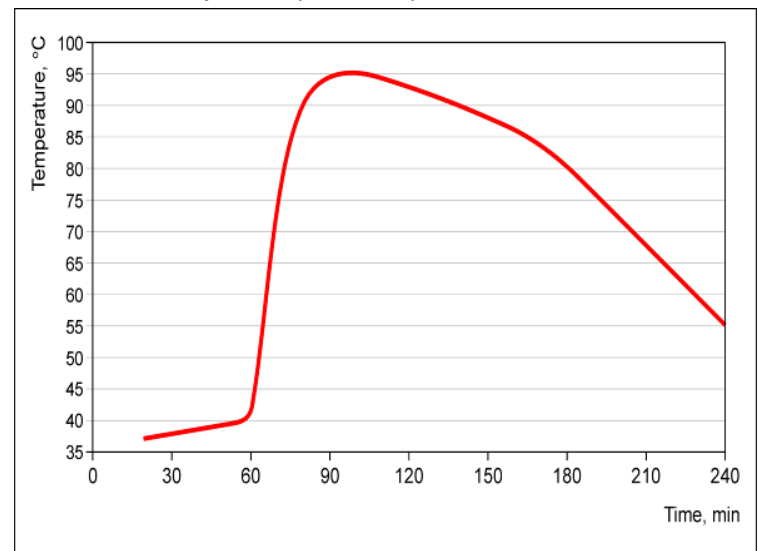

Figure 2 - Temperature of disposed ash, 50\% of solid, in function of time

When the concentration is between $40 \%$ and $60 \%$ (zone B) it comes to complete binding of technological water and swiftness of water binding goes from several hours (when it is $40 \%$ ) to less than 30 minutes (when it is $60 \%$ ). When mass concentration exceeds $60 \%$ (zone $\mathrm{C}$ ) reaction is exquisitely swift and it binds technological water in the time of 10-13 minutes. For industrial purpose mass concentration of $50 \%$ of ash was chosen. It assures complete binding and evaporation of used water with gradual solidification of disposed mass. At that concentration temperature increase is gradual in the first 50-60 minutes, but up to 90 minutes it becomes very intensive. Cooling process is slowed down and it lasts several hours (Figure 2). When temperature is equal to the surrounding temperature, visible process of solidification starts up and positive effects on the disposed mass stability are measurable after 24 hours.

\section{TPP "GACKO” ASH DISPOSAL SITE}

Ash disposal site was formed on an excavated area of "Gracanica" active coal open pit mine, Figure 3 and 4. Three cassettes were planned to completely fill up excavated area. Two cassettes, of equal sizes (roughly $500 \times 250 \mathrm{~m}$ ) have been activated till now.

Ash disposal site is completely prepared, including liner system on the bottom and lateral sides of embankment by HDPE geo-membrane, Figure 5.

Dry ash is pneumatically, by pressure vessels, transported in one of two concrete silos. Silos provide smooth operation of power plant in three shifts and ash disposal only in daylight time (12-16 h/day). Dry ash from silo $(90-150 \mathrm{t} / \mathrm{h})$ is feed into covered agitator of $32 \mathrm{~m}^{3}$ volume. Water is brought into agitator first then dry ash, Figure 6. Agitator is used for slurry preparation, i.e. it is where ash has contact with water and where hydration beginning. Slurry parameters regulation also takes place there. Hydraulic transport is performed through two pipelines (till the disposal site steel and on the disposal site plastic, ND $200 \mathrm{~mm}$ ). Pipeline length is up to $1670 \mathrm{~m}$ and pipelines are in constant downfall from the agitator to the disposal site location.

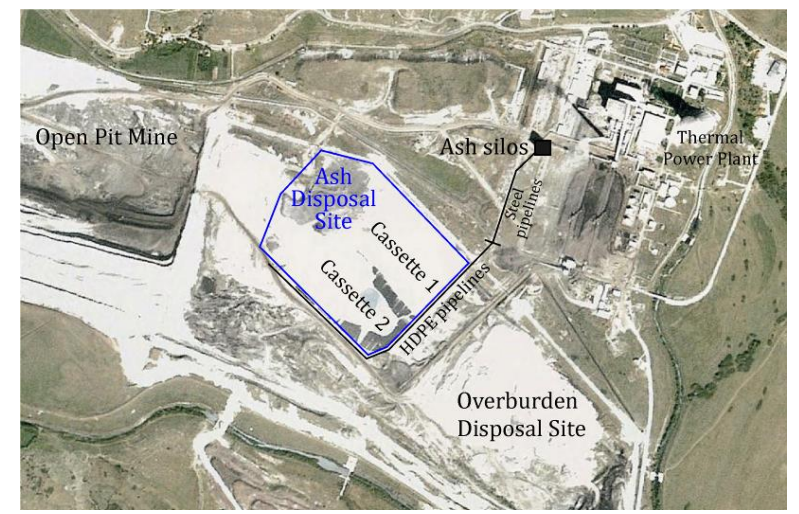

Figure 3 - Layout of TPP “Gacko” ash disposal site (Google earth)

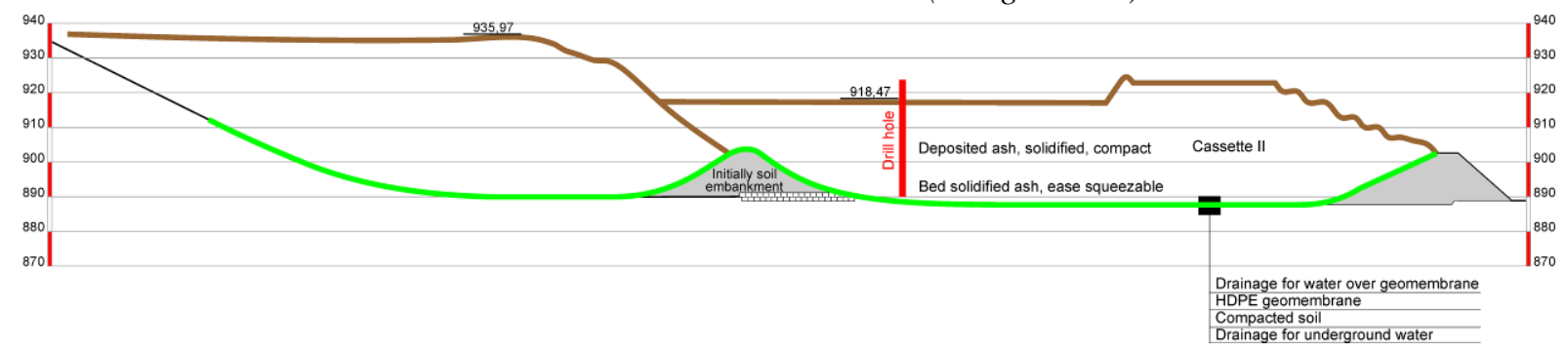

Figure 4 - Cross section through ash disposal site of TPP "Gacko” 


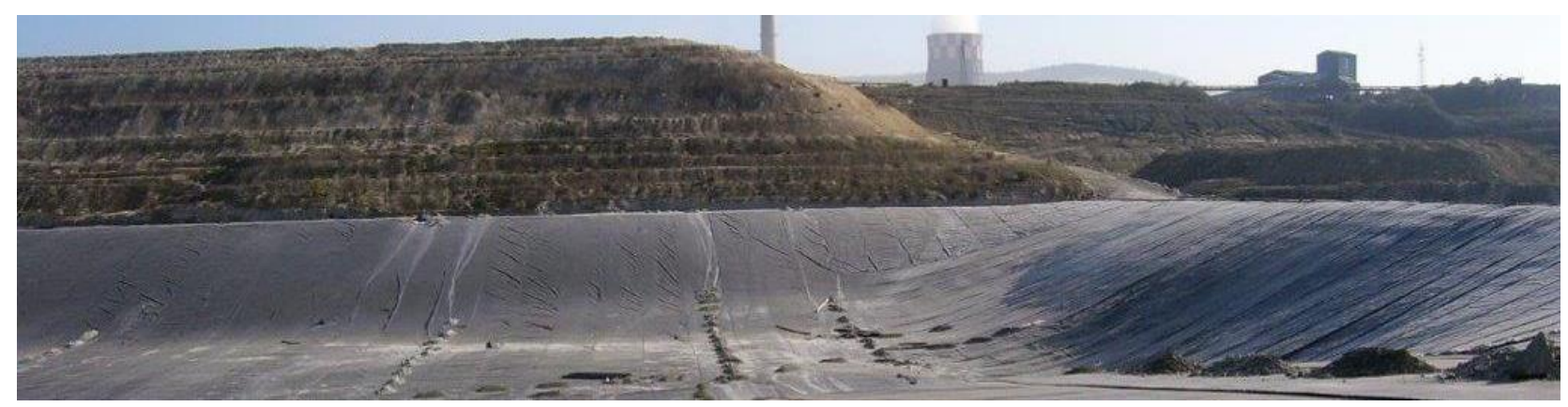

Figure 5 - Liner on bottom and on lateral side of initially embankment of ash disposal site

Given mass ratio between ash and water is $1: 1$, or $50 \%$ of solid, i.e. slurry density is $1482 \mathrm{~kg} / \mathrm{m}^{3}$. Usually system often operates with smaller concentration than designed, for

safety reasons (to prevent ash solidification into pipeline). Ash is directly discharged into prepared accumulation area. Ash layer thickness is small (up to $20 \mathrm{~cm}$ ) in every cycle.
Slurry preparation process is exothermic and reached temperatures for slurry density, from 1320 $\mathrm{kg} / \mathrm{m}^{3}$ (38\% of solid) and $1400 \mathrm{~kg} / \mathrm{m}^{3}(44.5 \% \mathrm{~S})$ are shown in the Table 1.

Slurry temperature measurement in the process of its preparation shows that greater influence on its temperature change has outside temperature and ash and water temperature than the process itself.

Table 1. Temperatures in the slurry preparation process for different slurry density

\begin{tabular}{|l|l|l|l|l|}
\hline \multirow{2}{*}{} & \multirow{2}{*}{ Sampling point } & \multicolumn{2}{l|}{ Temperature, ${ }^{\circ} \mathrm{C}$} \\
\cline { 3 - 4 } & & Winter time & Summer time \\
\hline Ambient & On disposal point & -2 & 23 \\
\hline Dry ash & Outlet from silo & 90 & 150 \\
\hline Water for slurry preparation & Inlet in water pump & 5 & 19 \\
\hline Slurry & $\begin{array}{l}\text { Outlet from } \\
\text { pipeline }\end{array}$ & $1320 \mathrm{~kg} / \mathrm{m}^{3}$ & 15 & 25 \\
\hline Return water & Inlet in water pump & $1400 \mathrm{~kg} / \mathrm{m}^{3}$ & 16 & 26 \\
\hline
\end{tabular}

\section{RESULTS OF SOLIDIFICATION PROPERTIES IN FUNCTION OF DISPOSAL SITE DEPTH AND AGE}

Slurry disposal and preparation process is based on ash feature to produces chemical reaction that condition solidification of disposed ash in relative brief time (Figure 2). Situation of disposed ash on the surface can only be visually evident, while the inner situation of disposed mass is not available. There is no free water on the surface, which may mean that all the water is used up in the solidification process or that is infiltrated in disposed mass. Subject of the research was: what is the situation of disposed mass by the depth of the disposal site, how the age affects on characteristics and what is the change effect of infiltrated water in the disposal site?

Ash samples for chemical analysis were taken below electrostatic precipitator. Slurry samples were taken on the spot of discharge in the disposal site. Samples of disposed ash were taken out of research drill hole, by sampling of the core. Drilling diameter was $146-116 \mathrm{~mm}$. Drilling depth was $26.25 \mathrm{~m}$. Location of drill hole is given in Figure 4.

Chemical composition is determined by using standard methods of chemical analysis. To determine mineralogical alterations samples were researched by the method of X-ray diffraction on the poly-crystal sample (dust) by using diffractometer Philips PW1710. Granulometric composition is determined by sieving on series of Tyler laboratory screens. Slurry density, temperature and temperature of air and water were determined on the very location. Geotechnical parameters were determined in accordance with Serbian standards.

Disposed ash compactness, water bearing and degree of solidification is expressively heterogeneous and anisotropic. It has distinct horizontal stratification. Per the characteristics of disposed ash, by the drill hole depth four characteristically layers were distinguished, Table 2. 


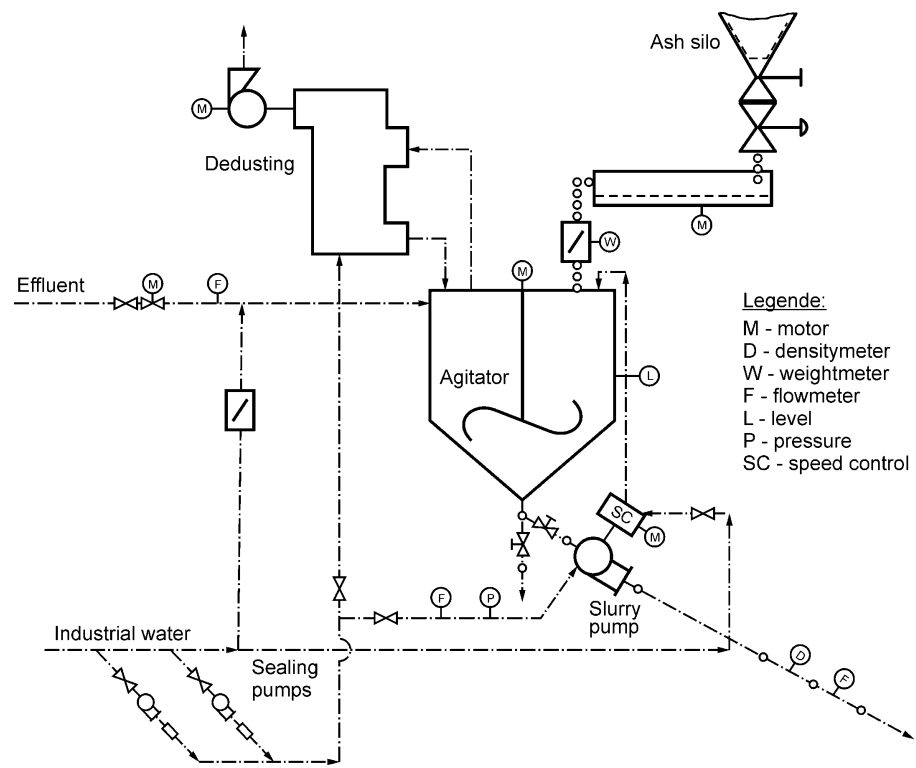

Figure 6 - Technological scheme of slurry preparation

Table 2. Layers in profile of drill hole

\begin{tabular}{|c|c|c|c|c|}
\hline \multicolumn{2}{|c|}{ Elevation, $\mathrm{m}$} & Depth, $\mathrm{m}$ & Lithological description of layers & Disposal time \\
\hline Upper & 918.47 & \multirow[b]{2}{*}{3.0} & \multirow{2}{*}{ Layer 1 - Medium solidified ash } & 4 months ago \\
\hline Lower & 915.47 & & & 1 year ago \\
\hline \multirow[b]{2}{*}{ Lower } & & \multirow[b]{2}{*}{ (11.50) 14.50} & \multirow[t]{2}{*}{ Layer 2 - Solidified, compact ash } & 2 years ago \\
\hline & 903.97 & & & 3 years ago \\
\hline \multirow[b]{2}{*}{ Lower } & \multirow[b]{2}{*}{899.67} & & \multirow[b]{2}{*}{$\begin{array}{l}\text { Layer } 1 \text { - Medium solidified ash } \\
\text { Level of free water }-18.8 \mathrm{~m}\end{array}$} & 4 years ago \\
\hline & & (4.30) 18.80 & & \multirow[t]{2}{*}{5 years ago } \\
\hline Lower & 897.47 & (2.20) 21.00 & Layer 3 - Bed solidified, ease squeezable & \\
\hline Lower & 892.22 & (5.25) 26.25 & Layer 4 - Insufficiently solidified, friable & 6 years ago \\
\hline
\end{tabular}

Appearance of free water is noted on depth of 18.8 $\mathrm{m}$, even though there is no free water on surface. Surface layer and layer above water is defined as a "medium solid", while between them there is "solid and compact" layer of disposed ash $11.5 \mathrm{~m}$ thick, Figure 7. Below water bearing layer there is insufficiently solidified, friable layer that does not contain free water.

Ash samples were taken out of depth and then examined. Results are shown in Table 3.

In all samples in chemical composition $\mathrm{CaO}$ prevail. It is made as a solid product of limestone calcinations in the coal combustion process. Involvement of $\mathrm{CaCO}_{3}$ in disposed ash shows that the process is partially reversible.

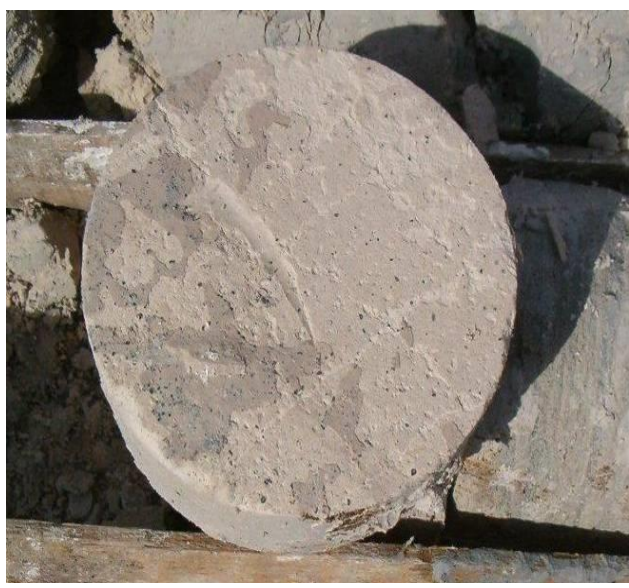

Figure 7 - Cross-section through the core of "solid and compact" ash layer 
Content of $\mathrm{SO}_{3}$ group is significant in dry ash, which implies the result - spontaneous desulphurization of coal in TPP's boiler. Content of $\mathrm{SO}_{3}$ group in disposed ash is less because it led to the reaction with free $\mathrm{CaO}$ and forming of gypsum minerals. Content of rest of the components in chemical composition is mainly subordinated, which is typical for this kind of ash.

By its mineral composition dry ash is dominantly made from calcium oxide with smaller content of calcium sulfate, calcium hydroxide, calcium silicate, alumina ferrite and increased quantities of anhydrite. Watched by the disposal site depth and age, Figure 8 , content of ettringite, portlandite, magnetite, calcite, olivine was determined.

The most common phases are ettringite and portlandite. Intensity of impulses of those minerals differs by the depth of sampling and it is seen by the diffractogram. The strongest intensity is reached during analysis of surface sample. As it goes deeper, intensity is decreasing.

Analysis of granulometric composition shows that dry ash is finely pulverized material of dust and clay size. Depending on age and water presence agglomeration occurs in disposal site.

Ash is separated as a dry, but in the process of slurry preparation it binds the water. Moisture is relatively constant and without substantial depth influence. The highest moisture is on level $899.67 \mathrm{~m}$, i.e. on the level when free water appears.
Volume masses are relatively small which is common for ashes. With the porosity of around 70\% and porosity coefficient above 2, sampled ash is classified into the group of coherent materials.

It is evident that the angle of inner friction is quite stabile, and the greatest values are in the layer of "solidified and compact" ash.

Cohesion is relatively equal by the depth of the disposed ash. Significant increase is on the depth of around $10 \mathrm{~m}$ in the layer that is defined as "solidified and compact ash". Slight decrease is in the layer where free water occurs at a depth of $18.80 \mathrm{~m}$.

Given results show that compressibility module depends of ash binding. When ash is solidified and compact it is high and indicates on less compressible material. While low and medium solidified ash module is between 6000 and $12000 \mathrm{kN} / \mathrm{m}^{2}$, which places it as a middle compressible material. The highest value was recorded around level 907 where ash is "solidified and compact". Decreasing trend, although very slow is recorded towards the bottom and towards the top of disposal site. In the layer where water is noted, module is unified and low.

Based on the results shown in the Table 3 it may conclude that relative compression is growing in both directions when it is viewed in relation to layer when ash is "solidified and compact". High relative compression in upper layers indicates on insufficient solidity of disposed ash, and in lower layers probably it is consequence of water presence.

Table 3. Results of disposed ash research

\begin{tabular}{|c|c|c|c|c|c|c|}
\hline \multicolumn{2}{|c|}{$\begin{array}{l}\text { Area where sample was taken, } \\
\text { descriptive }\end{array}$} & $\begin{array}{l}1-\text { Medium } \\
\text { solidified ash }\end{array}$ & $\begin{array}{l}2 \text { - } \\
\text { Solidified, } \\
\text { compact ash }\end{array}$ & $\begin{array}{l}3 \text { - Bed } \\
\text { solidified, ease } \\
\text { squeezable }\end{array}$ & $\begin{array}{l}4 \text { - Insuffici- } \\
\text { ently solidified, } \\
\text { friable }\end{array}$ & Dry ash \\
\hline \multicolumn{2}{|c|}{ Depth of sampling, $m$} & $1.5-2.0$ & $10.0-10.5$ & $19.0-19.5$ & $25.0-25.5$ & - \\
\hline \multicolumn{2}{|c|}{ Disposal time } & 4 months ago & 2 years ago & 5 years ago & 6 years ago & - \\
\hline \multicolumn{2}{|l|}{ Moisture, \% } & 75.0 & 82.9 & 86.0 & 72.0 & 0.13 \\
\hline \multirow{4}{*}{$\begin{array}{l}\text { Granulo-metric } \\
\text { composition }\end{array}$} & $<2 \mu \mathrm{m}$ & 22 & 6 & 9 & 18 & 23 \\
\hline & $2-60 \mu \mathrm{m}$ & 56 & 63 & 76 & 65 & 69 \\
\hline & $60 \mu \mathrm{m}-2 \mathrm{~mm}$ & 21 & 30 & 15 & 17 & 8 \\
\hline & $\geq 2 \mathrm{~mm}$ & 1 & 1 & 0 & 0 & 0 \\
\hline \multirow{7}{*}{$\begin{array}{l}\text { Chemical } \\
\text { composition }\end{array}$} & $\mathrm{SiO}_{2}$ & 8.82 & 4.92 & 9.90 & 6.14 & $11.5-12.4$ \\
\hline & $\mathrm{Al}_{2} \mathrm{O}_{3}$ & 4.89 & 3.80 & 5.69 & 4.27 & 9.6-11.7 \\
\hline & $\mathrm{Fe}_{2} \mathrm{O}_{3}$ & 3.82 & 2.20 & 3.10 & 2.97 & $3.2-4.5$ \\
\hline & $\mathrm{CaO}$ & 54.14 & 54.27 & 51.49 & 52.91 & $53.7-55.3$ \\
\hline & $\mathrm{MgO}$ & 1.15 & 1.44 & 1.47 & 1.18 & 4.4-5.9 \\
\hline & $\mathrm{SO}_{3}$ & 4.94 & 8.46 & 6.17 & 9.07 & $10.0-12.5$ \\
\hline & $\mathrm{CaCO}_{3}$ & 8.8 & 9.2 & 10.4 & 12.4 & \\
\hline \multirow{2}{*}{$\begin{array}{l}\text { Bulk density, } \\
\mathrm{t} / \mathrm{m}^{3}\end{array}$} & With moisture & 1.26 & 1.39 & 1.38 & 1.41 & \\
\hline & Dry & 0.72 & 0.76 & 0.74 & 0.82 & 0.91 \\
\hline \multicolumn{2}{|c|}{ Particle density, $\mathrm{t} / \mathrm{m}^{3}$} & 2.55 & 2.66 & 2.54 & 2.54 & 2.8 \\
\hline
\end{tabular}




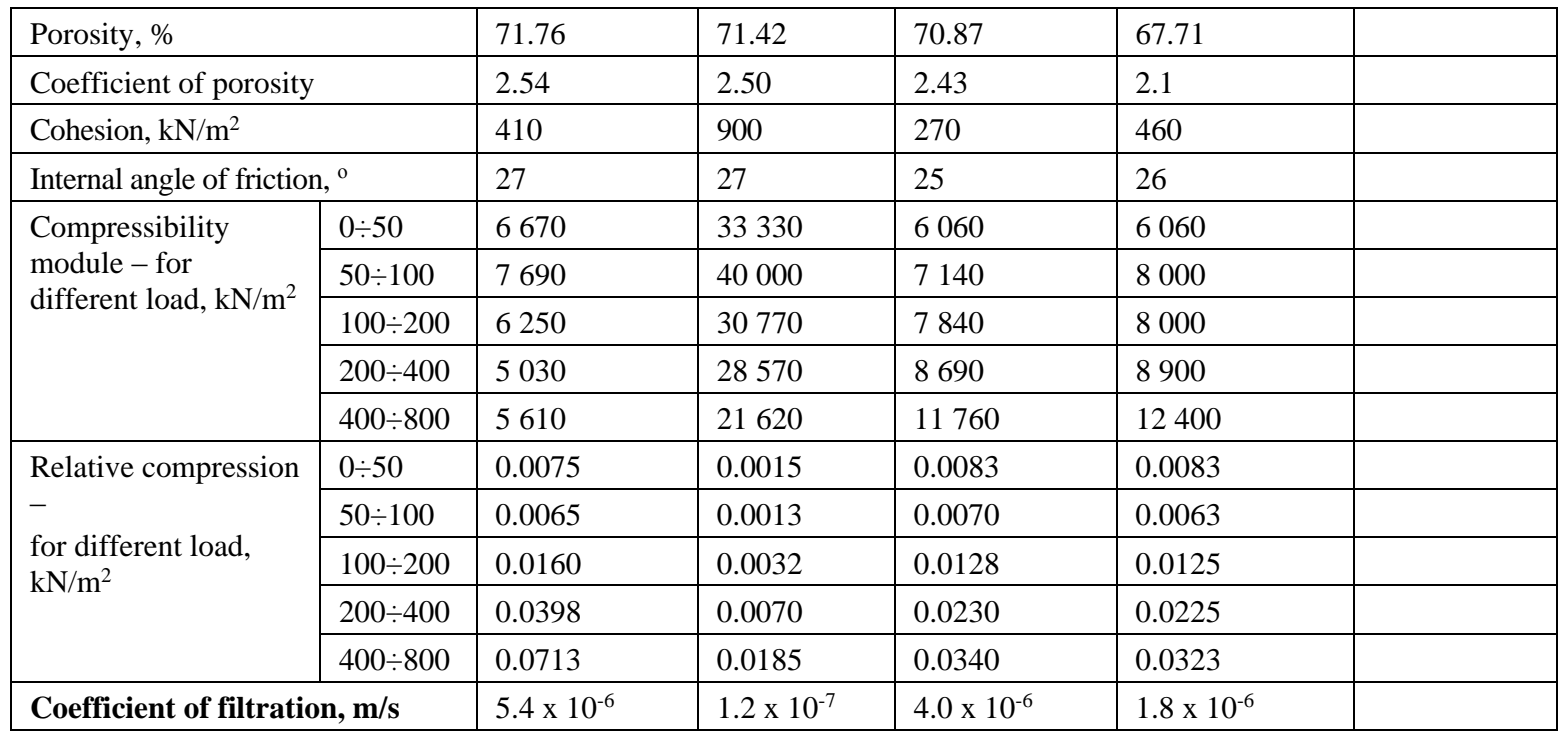

Results of filtration coefficient measurement depending on depth of disposed sample show that water permeability is between $10^{-6}$ and $10^{-7} \mathrm{~m} / \mathrm{s}$. The smallest water permeability is recorded in "layer 2" with the ash that is characterized as "solidified and compact". Given values show that situation of disposed ash on the cassette 2 is favorable insofar as the material is more compacted, less porous and therefore water movement through disposed ash is slower.

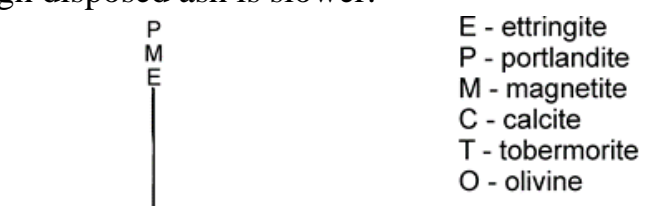

$\mathrm{O}$ - olivine

a)

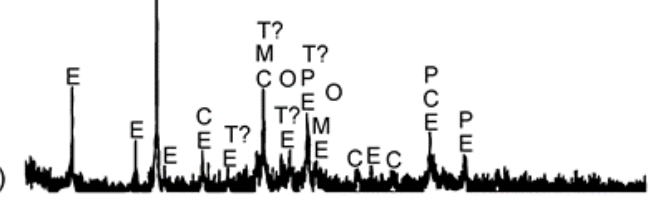

b)

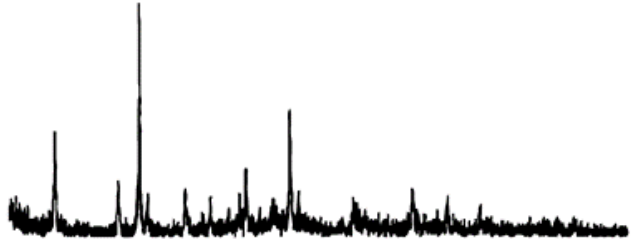

c)

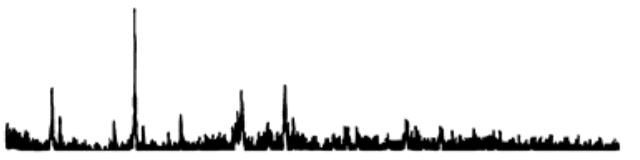

d)

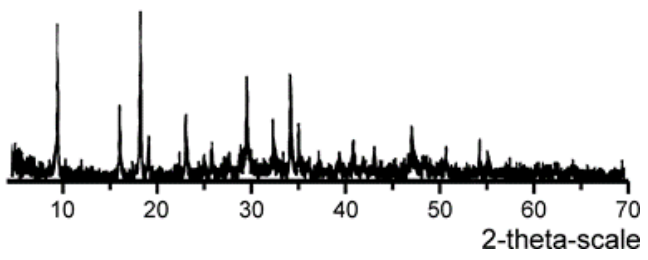

Figure 8 - Diffractogram of dust samples taken from various depths: a) $1.5-2.0 \mathrm{~m}$ b) $10.0-10.5$ m, c) $19.0-19.5 \mathrm{~m}, d) 25.0-25.5 \mathrm{~m}$

\section{CONCLUSION}

Situation of solidified ash on the disposal site of TPP "Gacko" was researched depending on the depth where it is located, i.e. depending on age of disposal.

Significant stratification of disposed ash and significant unevenness in terms of it solidification is noted. Four different layers were distinguished. Above free water there is medium solid (layer, marked 1), and solidified and compacted ash (2), in the layer of water there is weakly linked, easily squeezable ash (3), and below it there is insufficiently solidified, friable ash (4). It can be concluded that above the level of free water there is solidified ash, while the ash in and under the water bearing layer is insufficiently solidified.

As the time passes, inside disposed ash some changes occur in chemical and mineral composition. When $\mathrm{CaO}$ is in reaction with water and other components it becomes $\mathrm{CaCO}_{3}$, i.e. mineral transformation and mineral cement forming (ettringite, portlandite) occur.

Depending on disposal age and layer's state geotechnical parameters differ. The most favorable condition in terms of cohesion, angle of inner friction, compressibility module and relative compression is in the area 2 (solidified, compact ash), while the most unfavorable state is in water bearing layer.

By comparison of research results (laboratory and on pilot scale) and "in situ" measurements significant difference is noted in the solidification process efficiency. External factors (climate, temperature), consistency in conducting and constant of parameters of slurry preparation and preparation of disposal site (hydro insulation, drainage) have significant influence on self-solidification process. It can be concluded that the factors have significantly higher influence on the success of the process of solidification than just time 
of disposal. Amount of water that is in disposal site is of fundamental importance. Due to good water permeability, water filtration through disposal site conditions that lower layers are water bearing (disposal site is hydro insulated by geo-membrane) thus characteristics of disposed ash are significantly changed. Heterogeneity of layers and areas inside solidified ash should consider when calculating disposal site stability and assessment of environmental risk.

\section{REFERENCES}

[1] Kulkarni D, Lokeshappa B, Kandarp S, Anil K D, Mobilization of Metals from Indian Coal Fly Ash under Dynamic Conditions, World Environment, Vol. 2, No. 1, pp.1-6, 2012.

[2] ASTM Standard C33, Specification for Concrete Aggregates, ASTM International, West Conshohocken, PA, 2003. - Panteleev VG, Content and properties of ash and bottom ash of thermal power plant, Energoatomizdat, Leningrad, (in rusian), 1985.

[4] Melentjev VA (ed.), Ash and bottom ash and disposal site, Energija, Moskva, (in rusian), 1978.

[5] Knezevic D, Ash disposal as high concentration slurry, Elektroprivreda 3, Belgrade, pp. 107-111 (in Serbian), 1988.

[6] EPA/542-B-99-002, Solidification/Stabilization, Resource Guide, United States Environmental Protection Agency, Office of Solid Waste and Emergency Response (5102G), 1999.

[7] LaGrega, Michael D., Phillip L. Buckingham, and Jeffrey C. Evans. Hazardous waste management. Waveland Press, 2010.

[8] Santhanam CJ, Ullrich CR (eds.), Flue gas cleaning waste disposal and utilization, Noyes data corporration, Park Ridge, N.J. 1981.

[9] Côté, Pierre. Environmental aspects of stabilization and solidification of hazardous and radioactive wastes. Vol. 1033. ASTM International, 1989.

[10] Conner JR, Chemical Fixation and solidification of hazardous wastes, Van Nostrand Reinhold, New York, 1990.

[11]Jiang, W., X. Wu, and D. M. Roy. Alkali-activated fly ash-slag cement based nuclear waste forms. MRS Proceedings. Vol. 294. Cambridge University Press, 1992.

[12]Fan LT, 1989, Experimental Study of Stabilization/ Solidification of Hazardous Wastes, Kansas State University, EPA, 1992.

[13]Parsa, J, Munson-McGee, S. H, \& Steiner, R, Stabilization/solidification of hazardous wastes using fly ash. Journal of Environmental Engineering, Vol. 122, No. 10, pp. 935-940, 1996.
[14]Shi C, \& Fernandez-Jimenez, A, Stabilization/solidification of hazardous and radioactive wastes with alkali-activated cements. Journal of hazardous materials, Vol. 137, No.3, pp. 1656-1663, 2006.

[15]Anon, Cementation of radioactive waste, NUKEM Technologies GmbH, 2007.

[16]Agamuthu P, and Chitra S, Solidification/Stabilization Disposal of Medical Waste Incinerator Flyash Using Cement, Malaysian Journal of Science, Vol. 28, No. 3, pp. 241-255, 2009.

[17] Massardier V, Moszkowicz P, Taha M, Fly ash stabilization-solidification using polymer-concrete double matrices, European Polymer Journal, Elsevier, Vol. 33, No. 7, pp. 1081-1086, 1997.

[18]Karagiannidis A, Kontogianni S, Logothetis D, Classification and categorization of treatment methods for ash generated by municipal solid waste incineration: A case for the 2 greater metropolitan regions of Greece, Waste Management, Vol. 33, No. 2, pp. 363-372, 2013.

[19]Kozáková L', Bakalár T, Zeleňák M, Praščáková M, Solidification of MSWI fly-ash with regard to hazardous metals leaching, Acta Montanistica Slovaca, Vol. 18, No. 2, pp. 129-139, 2013.

[20] Cheng-Gang C, Chang-Jung S, Sue-Huai G, ChingWei W, Yu-Lun C, The effects of the mechanicalchemical stabilization process for municipal solid waste incinerator fly ash on the chemical reactions in cement paste, Waste Management, Vol. 33, pp. 858865, 2013.

[21]Diaz-Loya E. I, Allouche E N., Eklund S, Joshi A R., Kupwade-Pati K, Toxicity mitigation and solidification of municipal solid waste incinerator fly ash using alkaline activated coal ash, Waste Management 32, pp. 1521-1527, 2012.

[22]Agamuthu P, Chitra S, Satoshi M, Hiroshi T, Solidification and stabilization of Fly ash from mixed hazardous waste incineration using ordinary Portland cement, Environmental science, Vol. 13, No. 5, MY Tokyo, pp. 289-296, 2006.

[23] Anastasiadou K, Christopoulos K, Mousios E, Gidarakos E., Solidification/ stabilization of fly and bottom ash from medical waste incineration facility, J Hazard Mater. Elsevier B.V., Vol. 207, pp. 165170., 2012.

[24]Jing Z, Matsouka N, Jin F, Yamasaki N, Suzuki K, Hashida T, A Novel Method Of Advanced Materials Processing, Solidification of coal fly ash using hydrothermal processing method, Journal of materials science, Vol. 41, No. 5, Springer Science+Business Media, Inc, pp. 1579-1584, 2006.

[25]Branković B, Knežević D, Milošević M, Joksimović $\mathrm{V}$, Monevski B, Opportunities and conditions of ash 
disposal in „Kostolac-B“ thermal power plant, Rudarski glasnik, 1, Belgrade, pp. 53-59 (in Serbian), 1991.

[26]Kmiecik J. et al., A method of filling with simultaneous packing superficial storage yards with waste materials from power plants, thermal-electric power station and heating plants, European Patent Office, Bulletin no. 82/39, Patent no. 81102061.9

[27]Hycnar J, Skladowanie otpadow z elektrowni, Gaz, woda i technika sanitarna, No. 4, Katowice, pp. 100106,1985
[28]Knežević D, Practice and problems of ash and bottom ash transportation and disposal in Serbia and Montenegro, Proceedings of 1st congress of ash and bottom ash disposal site, Obrenovac, pp. 19-27.(in Serbian), 2005.

[29]Knežević D, Possibilities and conditions for ash selfsolidification ash generated from Kosovo-B Thermal Power Plant, Mining Science and Technology, No.12, Vol.1, Belgrade, pp. 19-36, 1996.

[30] Knežević D, Simović I, Vujičić Lj, Radoičić M, Disposal problems of high calcium ashies, TPP Gacko case, Proceedings of XII Yugoslav mineral processing symp., Tuzla, pp.347-352 (in Serbian), 1989.

\title{
REZIME
}

\section{ISPITIVANJE KARAKTERISTIKA OČVRSLOG PEPELA U ZAVISNOSTI OD DUBINE I VREMENA DEPONOVANJA, NA PRIMERU TERMOELEKTRANE „GACKO“}

\begin{abstract}
Sagorevanjem uglja na termoelektrani "Gacko" (Bosna i Hercegovina) izdvaja se pepeo sa visokim učešćem kalcijuma. Kontrolisanim mešanjem vode i pepela dolazi do spontane solidifikacije na deponiji pepela. Prethodnim istraživanjima je utvrđeno da brzina i efikasnost solidifikacije zavisi od učešća kalcijum-oksida u pepelu i masenog odnosa voda:pepeo, a kao najpodesniji za industrijsku primenu odabran je maseni odnos (približno) 1:1. Posle 6,5 godina eksploatacije, iz istražne bušotine, uzeti su uzorci pepela različite starosti $i$ analizirane njihove hemijske, fizičke, mineraloške $i$ geotehničke karakteristike. Deponovani pepeo je bio uslojen i veoma heterogen. Pokazano je da na efikasnost procesa solidifikacije u praksi veliki uticaj imaju klimatske prilike, pravilno vođenja pripreme hidromešavine, kontinuiranost u radu i uređenje deponije. Posebno je uočen veliki uticaj vode koja se, zbog dobre vodopropustljivosti, filtrira u donje slojeve i bitno menja njihove karakteristike.
\end{abstract}

Key words: deponija pepela TE "Gacko", pepeo sa visokim učešćem kalcijuma, spontana solidifikacija, karakteristike deponovanog pepela 